\title{
Effects of Alumina and White Fused Alumina Addition on Transparent Wall and Floor Tile Glazes
}

\author{
B. Yildiz ${ }^{a *}$, Z. B. OzTURK ${ }^{b}$, A. KARA ${ }^{c, d}$ \\ ${ }^{a}$ Yurtbay Seramik, Oklubalı Köyü İnönü/Eskişehir, Türkiye \\ ${ }^{b}$ Nevşehir Hacı Bektaş Veli University, Faculty of Engineering and Architecture, \\ Department of Metallurgical and Materials Engineering, Nevşehir, Türkiye \\ ${ }^{c}$ Ceramic Research Centre (SAM), Eskişehir, Türkiye \\ ${ }^{d}$ Anadolu University, Faculty of Engineering, Department of Materials Science \\ and Engineering, Eskişehir, Türkiye
}

\begin{abstract}
In tile manufacturing, $\alpha-\mathrm{Al}_{2} \mathrm{O}_{3}$ is the main type of alumina used in ceramic body and glaze formulations. This raw material acts as an opacifier in porcelain tile bodies and as a matting agent in glazes. White fused alumina (WFA) is produced by fusing calcined alumina in an electric arc furnace under carefully controlled conditions. It is usually employed in floor tile glazes in order to increase their abrasion resistance. The aim of this study was to establish a better understanding of how alumina and white fused alumina addition affects the thermal behavior and aesthetic properties of wall and floor tile transparent glazes. It was shown that both alumina and fused alumina increased the softening temperatures of the standard glaze composition. Corund was the main detected phase in tile glazes incorporated with fused alumina. This result suggested that white fused alumina did not react with glassy phase to form any other crystalline phases. This result can be attributed to higher refractoriness of white fused alumina. Presence of anorthite and gahnite phases was, on the other hand, observed in the glazes with alumina addition. It was further shown that alumina was more effective in increasing opacity and reducing glossiness compared to white fused alumina.
\end{abstract}

DOI: 10.12693 /APhysPolA.127.1090

PACS: 81.05.Je

\section{Introduction}

Alumina is a synthetic raw material manufactured from bauxite by the Bayer process, whose $\mathrm{Al}_{2} \mathrm{O}_{3}$ content is typically higher than $99 \mathrm{wt} . \%$. In tile manufacturing, $\alpha-\mathrm{Al}_{2} \mathrm{O}_{3}$ is the main type of alumina used in body and glaze formulations [1-3]. This raw material acts as an opacifier in porcelain tiles and as a matting agent in glazes [1, 3-6] The matt effect in the glaze depends on particle size and content of alumina. The refractory behaviour of alumina provides a glass matrix with undissolved particles that hinder the obtainment of smooth surfaces [1]. Fused alumina (formed in electric arc furnaces) comes in various forms, the most common of which are white (WFA) and brown (BFA). Fused alumina is a granular material with a high density, low porosity, low permeability and high refractoriness. In general, fused alumina has a melting point of approximately $2500^{\circ} \mathrm{C}$ and a Mohs hardness of 9 . WFA is the purer (higher grade) form, which consequently is used most readily in refractories. WFA is made from Bayer process alumina and is a friable product. Like BFA, WFA is also used in the manufacturing of grinding wheels (both vitrified and resin bonded) and coated products. These grains are also used for shot blasting purpose and as polish-

*corresponding author; e-mail: betulkarademir@gmail.com ing media; refractory grade WFA is used as raw material for high alumina refractories [7]. In ceramic tile manufacture, it generally used in floor tile glazes to increase abrasion resistance of the surface.

This study was undertaken in order to establish a better understanding of how alumina and white fused alumina incorporation in various amounts in both wall and floor tile transparent glazes effects their thermal behavior and aesthetic properties. For this purpose; representative glaze compositions were prepared by using industrial raw materials. The effect of compositional changes on thermal behavior, phase evolution and optical properties of the resultant glazes were investigated.

\section{Experimental procedure}

In the study, alumina $(\mathrm{d}(0.1): 30.4 \mu \mathrm{m}, \mathrm{d}(0.5): 69.6 \mu \mathrm{m}$, $\mathrm{d}(0.9): 133.3 \mu \mathrm{m})$ and white fused alumina $(\mathrm{d}(0.1): 16.8 \mu \mathrm{m}, \quad \mathrm{d}(0.5): 42.4 \quad \mu \mathrm{m}, \quad \mathrm{d}(0.9): 88.9 \mu \mathrm{m})$ were added into wall and floor tile transparent glaze compositions. For both wall and floor tile glaze preparation, 92 wt.\% wall or floor tile transparent frit, 8 wt.\% kaolin, 9-18-36 wt.\% alumina or fused alumina and 40 wt.\% water and suitable amount of carboxy methyl cellulose (CMC), sodium tripolyphosphate (STPP) were used. Chemical composition of the transparent wall and floor tile frits was determined by using Seger formulation. Chemical composition of the kaolin was, however, measured by wet chemical analyses (Table I). The glaze was milled in a fast laboratory mill until reaching a reject between 1.0 and $1.5 \mathrm{wt} . \%$, in a $\neq 325$ 
sieve (aperture of $45 \mu \mathrm{m}$ ). Prepared glazes were applied on the wall and floor tiles by a ragle with $0.55 \mathrm{~mm}$. thickness and fired in an industrial roller kilns. The firing regimes used in the study were; $1122^{\circ} \mathrm{C}$ in a 31 min. cycle (from cold to cold) for wall tile and $1195^{\circ} \mathrm{C}$ in a $35 \mathrm{~min}$. firing cycle (from cold to cold) for floor tile.

Standard frit recipes and kaolin.

TABLE I

\begin{tabular}{c|c|c|c}
\hline \hline $\begin{array}{c}\text { Oxide } \\
\text { [wt.\%] }\end{array}$ & $\begin{array}{c}\text { Transp. frit } \\
\text { for wall tile } \\
\text { glaze prep. }\end{array}$ & $\begin{array}{c}\text { Transp. frit } \\
\text { for floor tile } \\
\text { glaze prep. }\end{array}$ & Kaolin \\
\hline $\mathrm{CaO}+\mathrm{MgO}$ & 16.5 & 15.2 & 0.4 \\
$\mathrm{~K}_{2} \mathrm{O}+\mathrm{Na}_{2} \mathrm{O}$ & 4.2 & 4.9 & 1.5 \\
$\mathrm{ZnO}$ & 6.5 & 6.8 & - \\
$\mathrm{Al}_{2} \mathrm{O}_{3}$ & 7 & 6.7 & 36.5 \\
$\mathrm{~B}_{2} \mathrm{O}_{3}$ & 4.3 & 2.8 & - \\
$\mathrm{SiO}_{2}$ & 61.5 & 63.6 & 48.1 \\
$\mathrm{Fe}_{2} \mathrm{O}_{3}$ & - & - & 1.1 \\
L.O.I* & - & - & 12.4 \\
*L.O.I: loss on ignition & &
\end{tabular}

Sintering behaviour of the glazes was characterized by hot stage microscopy. The milled compositions, with particles smaller than $63 \mu \mathrm{m}$, were pressed in a mould $(3 \mathrm{~mm} \times 3 \mathrm{~mm} \times 3 \mathrm{~mm})$ and heated from room temperature to $400^{\circ} \mathrm{C}$ at a heating rate of $50^{\circ} \mathrm{C} / \mathrm{min}$. and from $400^{\circ} \mathrm{C}$ to $1400^{\circ} \mathrm{C}$ at a heating rate $10^{\circ} \mathrm{C}$. XRD analyses of the the glazes were conducted by a Rigaku Rint 2000 series diffractometer with $\mathrm{CuK} \alpha$ radiation working at $40 \mathrm{kV}$ and $30 \mathrm{~mA}$, with the scanning velocity of $2^{\circ} / \mathrm{min}$. The chromatic coordinates of the fired samples were measured by means of a Minolta CR-300 series chromo-meter. Gloss was measured with a gloss meter (Minolta Gloss 268 ) with a $60^{\circ}$ light incident angle on the glaze surface.

\section{Results and discussion}

\subsection{Sintering behaviour of the glazes}

Critical temperatures of the wall and floor tile glazes measured by hot stage microscopy are given in Table II and Table III, respectively. The sintering temperature of the wall tile glazes changed in a range of $\approx 900-970{ }^{\circ} \mathrm{C}$; softening temperature changed in $\approx 1050-1360{ }^{\circ} \mathrm{C}$; sphere temperature changed in $\approx 1080-1130{ }^{\circ} \mathrm{C}$; half sphere temperature changed in $\approx 1170-1260^{\circ} \mathrm{C}$ and melting temperature changed in $\approx 1200-1380^{\circ} \mathrm{C}$ ranges. Table II shows that most of the critical temperatures of the invesitigated glazes were higher than the standard glaze. Maximum amount alumina and white fused alumina addition (36 wt.\%) increased the softening temperature of the standard wall tile glaze from $1046^{\circ} \mathrm{C}$ to $1358^{\circ} \mathrm{C}$ and $1120^{\circ} \mathrm{C}$, respectively. The results showed that alumina was more effective in increasing the critical temperatures of the standard wall tile glaze.

When the standard wall and floor tile glazes were compared; the floor tile glaze showed higher critical temperatures than the wall tile glaze, as expected. The sintering temperature of the floor tile glaze changed in a range of $\approx 950-1100^{\circ} \mathrm{C}$; softening temperature changed in $\approx 1100-1390^{\circ} \mathrm{C}$; sphere temperature changed in $\approx 1140-1190^{\circ} \mathrm{C}$; half sphere temperature changed in $\approx 1200-1320^{\circ} \mathrm{C}$ and melting temperature changed in $\approx 1260-\left(>1400^{\circ} \mathrm{C}\right)$ ranges. Alumina and WFA addition affected the the critical temparatures of the standard floor tile in a similar way to that of the wall tile glaze. Alumina addition increased the critical temperatures of the standard floor tile glaze more than white fused alumina. In spite of the fact that 36 wt.\% WFA addition into the floor tile glaze increased its melting temperature from $1262^{\circ} \mathrm{C}$ to $1340^{\circ} \mathrm{C}$; melting temperature could not be measured in floor tile glaze with 36 wt.\% alumina addition since its melting temperature is probably higher than the working range of the hot stage microscope $\left(1400^{\circ} \mathrm{C}\right)$.

Hot stage microscope analyses of wall tile

TABLE II glazes $\left[{ }^{\circ} \mathrm{C}\right]$.

\begin{tabular}{c|c|c|c|c|c}
\hline \hline Wall tile glazes & $\mathrm{T}_{\text {Sint }}$ & $\mathrm{T}_{\text {Soft }}$ & $\mathrm{T}_{\text {Sph }}$ & $\mathrm{T}_{\text {H-Sph }}$ & $\mathrm{T}_{\text {Melt }}$ \\
\hline STD Wall Tile Glaze & 920 & 1046 & 1080 & 1170 & 1206 \\
STDW+9 wt.\% Alumina & 920 & 1084 & 1132 & 1188 & 1214 \\
STDW+18 wt.\% Alumina & 914 & 1200 & - & 1262 & 1280 \\
STDW+36 wt.\% Alumina & 970 & 1358 & - & - & 1384 \\
STDW+9 wt.\% WFA & 908 & 1044 & 1088 & 1164 & 1236 \\
STDW+18 wt.\% WFA & 912 & 1056 & 1100 & 1172 & 1218 \\
STDW+36 wt.\% WFA & 912 & 1120 & - & 1246 & 1278
\end{tabular}

Hot stage microscope analyses of floor tile glazes $\left[{ }^{\circ} \mathrm{C}\right]$.

\begin{tabular}{c|c|c|c|c|c}
\hline \hline Floor tile glazes & $\mathrm{T}_{\text {Sint }}$ & $\mathrm{T}_{\text {Soft }}$ & $\mathrm{T}_{\text {Sph }}$ & $\mathrm{T}_{\text {H-Sph }}$ & $\mathrm{T}_{\text {Melt }}$ \\
\hline STD Floor Tile Glaze & 944 & 1094 & 1138 & 1198 & 1262 \\
STDF+9 wt.\% Alumina & 978 & 1148 & 1190 & 1236 & 1290 \\
STDF+18 wt.\% Alumina & 1004 & 1248 & - & 1294 & 1322 \\
STDF+36 wt.\% Alumina & 1096 & 1392 & - & - & - \\
STDF+9 wt.\% WFA & 970 & 1104 & 1156 & 1224 & 1292 \\
STDF+18 wt.\% WFA & 968 & 1108 & 1156 & 1220 & 1280 \\
STDF+36 wt.\% WFA & 990 & 1222 & - & 1316 & 1340
\end{tabular}

\subsection{Phase analysis of the glazes}

Representative XRD spectra of the invesitigated wall tile and floor tile glazes are shown in Fig. 1 and 2, respectively. As expected, standard wall tile glaze showed amorphous structure. Corund was the only crystalline phase detected in the glazes with white fused alumina. This result suggested that WFA did not cause to form any other crystalline phases. This result can be explained by its high refractoriness. From Fig. 1, it was also seen that corund phase intensity increased with increased amount of fused alumina addition.

Residual of quartz was the only crystalline phase detected in the standard floor tile glaze. Corund was again the main phase in floor tile glazes with fused alumina addition. Anorthite $\left(\mathrm{CaO} \cdot \mathrm{Al}_{2} \mathrm{O}_{3} \cdot \mathrm{SiO}_{2}\right)$ and gahnite $\left(\mathrm{ZnO} \cdot \mathrm{Al}_{2} \mathrm{O}_{3}\right)$ phases were detected in the glazes with alumina addition. Bou et al. [1] also detected the anorthite and gahnite phases in their study while studying the effect of alumina on transparent glaze. They suggested 
that anorthite formation was caused by $\mathrm{Al}_{2} \mathrm{O}_{3}$ dissolution in the glassy phase surrounding the alumina particles, where the presence of $\mathrm{CaO}$ and $\mathrm{SiO}_{2}$ from the glassy phase favours anorthite crystallisation. Gahnite formation appears to be caused by diffusion of the zinc oxide present in the glassy phase inwards into the alumina particles. New crystalline phases (anorthite and gahnite) could also be the reason for the higher critical temperatures of the floor tile glazes with alumina addition. When $\mathrm{CaO}$ and $\mathrm{ZnO}$ are moved from glassy phase to form crystalline phases, the viscosity of the residual the glassy phase may have caused to increase the softening temperature by hindering viscous flow.

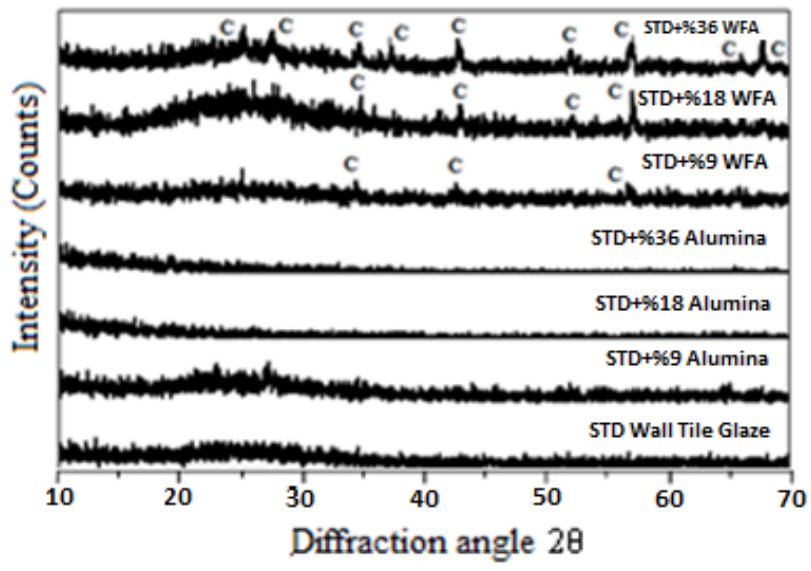

Fig. 1. XRD spectra of the transparent wall tile ceramic glazes (C: Corund).

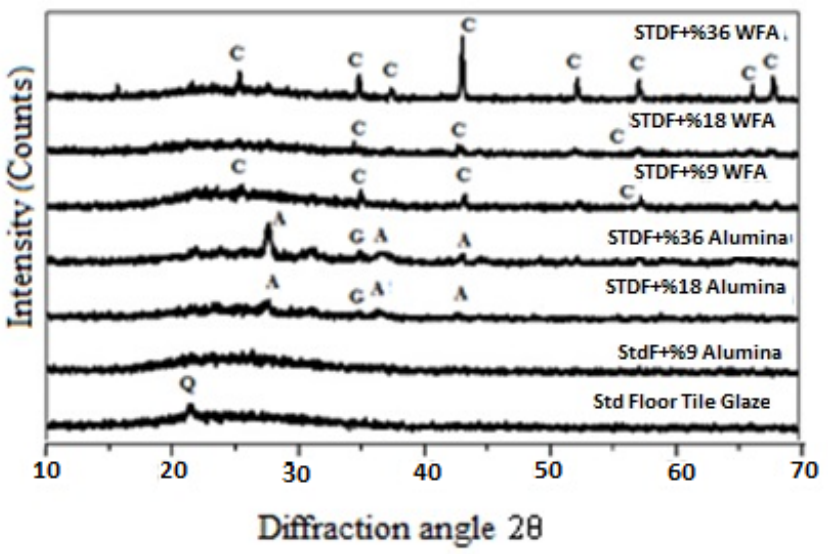

Fig. 2. XRD spectra of the floor tile ceramic glazes (C: corund, Q: quartz, A: anorthite, G: gahnite).

\subsection{Optical properties of the glazes}

Tables IV and V show colour and gloss $\left(60^{\circ}\right)$ values of the glazes obtained from the glaze surfaces. Transparency or opacity of a glaze depends mainly on two factors: i) abundance and crystal size distribution of the crystalline material and, ii) difference of refractive index between the crystals and the glass [8]. The $\mathrm{L}^{*}$ indice of the glaze could be a good value for comparing the opacity of the glazes. When the opacities are compared, it is seen that both alumina and white fused alumina addition to the standard glaze increased the opacity of glaze but alumina was more effective than the fused alumina. This result can be attributed to the formation of new crystalline phases (anorthite and gahnite) which could caused higher light scattering area and higher opacity.

All of the studied glazes showed lower glossiness than the standard transparent glazes. This result can be explained by the refractory nature of crystalline phases; behaves as a skeleton which hinders densification. Another reason could be the change in the composition of glassy phase when the new crystalline phases crystallize. When the anorthite and gahnite phases were formed in glazes, this caused reducing the quantity of fluxing oxides in the glassy phase. This change in glass composition raises viscosity, which prevents surface smoothing and gives rise to a rough surface and a matt appearance $[1,9]$ Glazes with white fused alumina addition also showed lower glossiness than the standard floor tile glaze. The refractory nature of the fused alumina provides a glass matrix with undissolved particles that hinder the obtainment of smooth surfaces. When the wall and floor tile glossiness were compared; the floor tile glazes show higher glossiness than the wall tiles. This result can be explained by the higher firing temperature in floor tile production.

Chromatic coordinates and the glossiness

TABLE IV of the wall tile glazes.

\begin{tabular}{c|c|c|c|c}
\hline \hline Wall tile glazes & $\mathrm{L}^{*}$ & $\mathrm{a}^{*}$ & $\mathrm{~b}^{*}$ & Glossiness $\left[60^{\circ}\right]$ \\
\hline STD Wall Tile & 78.2 & 5.73 & 17.81 & - \\
STD Wall Tile Glaze & 74.8 & 6.2 & 17.8 & 91.8 \\
STD+9 wt.\% Alumina & 80.3 & 4.3 & 8.9 & 57.9 \\
STD+18 wt.\% Alumina & 86.3 & 1.7 & 2.7 & 1.4 \\
STD+36 wt.\% Alumina & 93.2 & 0.3 & 0.6 & 1.7 \\
STD+9 wt.\% WFA & 76.2 & 5.6 & 15.9 & 71.7 \\
STD+18 wt.\% WFA & 78.17 & 4.93 & 15 & 76.9 \\
STD+36 wt.\% WFA & 81.7 & 3.6 & 9.7 & 11.2
\end{tabular}

Chromatic coordinates and the glossiness

TABLE V of the floor tile glazes.

\begin{tabular}{c|c|c|c|c}
\hline \hline Floor tile glazes & $\mathrm{L}^{*}$ & $\mathrm{a}^{*}$ & $\mathrm{~b}^{*}$ & Glossiness $\left[60^{\circ}\right]$ \\
\hline STD Floor Tile & 54.82 & 5.15 & 12.66 & - \\
STD Floor Tile Glaze & 59.07 & 3.84 & 9.65 & 93.2 \\
STDF+9 wt.\% Alumina & 69.14 & 1.57 & 0.66 & 62 \\
STDF+18 wt.\% Alumina & 80.24 & -0.17 & 2.4 & 4.6 \\
STDF+36 wt.\% Alumina & 91.84 & -0.56 & -0.91 & 3 \\
STDF+9 wt.\% WFA & 62.99 & 3.37 & 8.38 & 84 \\
STDF+18 wt.\% WFA & 63.61 & 3.31 & 8.07 & 81.4 \\
STDF+36 wt.\% WFA & 71.86 & 1.6 & 4.07 & 20.8
\end{tabular}

\section{Conclusions}

This study examines the effect of alumina and white fused alumina (WFA) on the thermal behavior and aesthetic behavior of wall and floor tile transparent glazes. The following conclusions can be drawn: 
Both alumina and white fused alumina addition to the glazes increased the critical temperatures, but alumina was found to be more effective.

Corund was the only detected phase in the glazes with white fused alumina addition. This result suggested that white fused alumina did not react with glassy phase to form any other crystalline phases.

Anorthite and gahnite formation in the glazes with alumina addition suggested that alumina reacted with $\mathrm{CaO}$, $\mathrm{ZnO}$ and $\mathrm{SiO}_{2}$ in the glassy phase. When $\mathrm{CaO}$ and $\mathrm{ZnO}$ are moved from glassy phase to crystalline phase, the viscosity of the residual glassy phase decreases which causes higher softening temperature. Higher amount of crystal formation in the structure could also be caused to increase softening temperature by hindering viscous flow.

The $\mathrm{L}^{*}$ indice of the glaze could be a good value for comparing the opacity of the glazes. When the difference of $\mathrm{L}^{*}$ indices of unglazed wall tile and glazed tile increase, it could be said that opacity of the glaze is increased. Both alumina and white fused alumina addition increased opacity, but alumina was more effective. This result can be explained by the formation of new crystalline phases (anorthite and gahnite) which could caused higher light scattering area and higher opacity.

Both alumina and white fused alumina addition decreased glossiness; but alumina was more effective. This result can be attributed to anorthite and gahnit formation which caused reducing the quantity of fluxing oxides, in the glassy phase. This change in glass composition raises viscosity, which prevents surface smoothing, giving rise to a rough surface and a matt appearance. In addition the crystalline phase, itself could also make a rough surface. Glazes with white fused alumina addition also showed lower glossiness than standard floor tile glaze. The refractory behaviour of the fused alumina provides a glass matrix with undissolved particles that hinder the obtainment of smooth surfaces.

The results suggested that small amount of white fused alumina addition could also be studied in floor tile glazes $(<9$ wt.\%) to obtain glazes with higher softening point. Such study could help to avoid pinhole problem without changing the aesthetic properties of the fired glaze.

\section{References}

[1] E. Bou, J. Garcia-Ten, R. Perez, S. Arrufat, G. Atichian, Bol. Soc. Esp. Ceram. 49, 271 (2010).

[2] K. Minssen, Ceram. Eng. Sci. Proc. 18, 308 (1997).

[3] R.A. Eppler, Adv. Sci. Technol. 34, 43 (2003).

[4] F. Campa, F. Gines, J. Robles, Qualicer, VI World Congress on Ceramic Tile Quality, Castellón: Cámara Oficial de Comercio, Industria y Navegación, 15 (2000).

[5] E. Quinteiro, J.C. Carvalho, B.A. Menegazzo, A.P.M. Manegazzo, V.A. Silva, N.G. Silva, Qualicer, VIII World Congress on Ceramic Tile Quality, Castellón: Cámara Oficial de Comercio, Industria y Navegación, 143 (2004).
[6] M.F. Tomizaki, S. Shinkai, J. Ceram. Soc. Jap., Int. Ed. 103, 330 (4).

[7] http://www.washingtonmills. com/download/116.

[8] M.L. Sanchez, M.J. Cabrera, A. Foo, H. Beltran, J.B. Carola, Qualicer, VII World Congress on Ceramic Tile Quality, Castellón: Cámara Oficial de Comercio, Industria y Navegación, 239 (2002).

[9] E. Bou, M.C. Bordes, C. Feliu, M.F. Gazulla, F. Ferr, G. Pasies, Qualicer, VII World Congress on Ceramic Tile Quality, Castellón: Cámara Oficial de Comercio, Industria y Navegación, 349 (2002). 